\title{
Study on Correlation of English Pronunciation Self-Concept to English Learning
}

\author{
Xin Tang ${ }^{1}$, Shengqi Zhang ${ }^{2}$, Yucong $\mathrm{Li}^{2} \&$ Miqiang Zhao ${ }^{2}$ \\ ${ }^{1}$ Foreign Languages Department, Beijing Institute of Petro-chemical Technology, Beijing, China \\ ${ }^{2}$ Department of Information Engineering, Beijing Institute of Petro-chemical Technology, Beijing, China \\ Correspondence: Xin Tang, Foreign Languages Department, Beijing Institute of Petro-chemical Technology, \\ Beijing, China. Tel: 86-136-4132-8122. E-mail: my2007story@163.com
}

\author{
Received: January 26, 2013 Accepted: February 15, 2013 Online Published: March 10, 2013 \\ doi:10.5539/elt.v6n4p74 URL: http://dx.doi.org/10.5539/elt.v6n4p74
}

\begin{abstract}
English pronunciation self-concept is formed in the process of pronunciation learning, which refers to the learners' self-conception and assessment of one's English pronunciation proficiency and pronunciation (Gimson, A. C. 1980). This paper reports an investigation on 237 non-English major college students into the relationship between English pronunciation self-concept and English performance, global English self-concept, English classroom anxieties; the relationship between global English self-concept and the sub-dimension of it. It was found that a moderate but statistically significant correlation obtained. Furthermore, English pronunciation self-concept correlated significantly to the global English self-concept and the latter exhibited a relatively high correlation to the English performance which is presented by test scores. These results suggest that language learners' pronunciation self-concept is one of the most important factors which facilitate or hinder foreign language learning. Meanwhile, it has a negative correlation to English class anxiety (Arnold, J., 1999). Therefore, conclusion can be drawn that constructive suggestions are supposed to be put forward and endeavor should be made to improve one's English pronunciation self-concept to facilitate the English acquisition.
\end{abstract}

Keywords: English pronunciation self-concept, English learning, global English self-concept, classroom anxieties, correlation

\section{Introduction}

\subsection{English Pronunciation Self-Concept}

In the process of foreign language learning pronunciation is the primary and inevitable issue. Vocabulary can be identified and memorized by pronunciation; speaking and listening can be delivered by it (Gass, S. \& L. Selinker, 2001). As far as non-English major students are concerned, English pronunciation is thought generally equated to English proficiency. Foreign language learning tends to sustain when one is admired by others for his pronunciation, while the motivation of foreign language learning is weakened by the negative assessment of others. This reasoning has been proved (Chuming Wang, 2004).

The self-assessment based on pronunciation relates to self-concept in the field of psychology (Guay, F., H. M. Marsh \& M. Boivin, 2003). Attaching importance to the study of pronunciation in the process of foreign language learning contributes to the improvement of foreign language education practically. Self-concept refers to one's self-perception which is formed by one's experience from the surroundings and the understanding and judgment of it (Hattie, 1986). Self-concept is not an internal entity which exists in individuals but an imaginary modal which possess the potential to interpret and foreshadow one's behavior. Self-concept is a multi-dimension and multi-hierarchy modal in which global self-concept is the superlative degree. Marsh and Shavelson (1985) classified self-concept into academic self-concept and non-academic self-concept. English self-concept composes academic self-concept with other self-concepts such as mathematics, history and so on. Meanwhile, English self-concept can be classified into English pronunciation self-concept, English listening self-concept, and English reading self-concept and so on (Marsh, H. W. \& A. S. Yeung, 1993). 


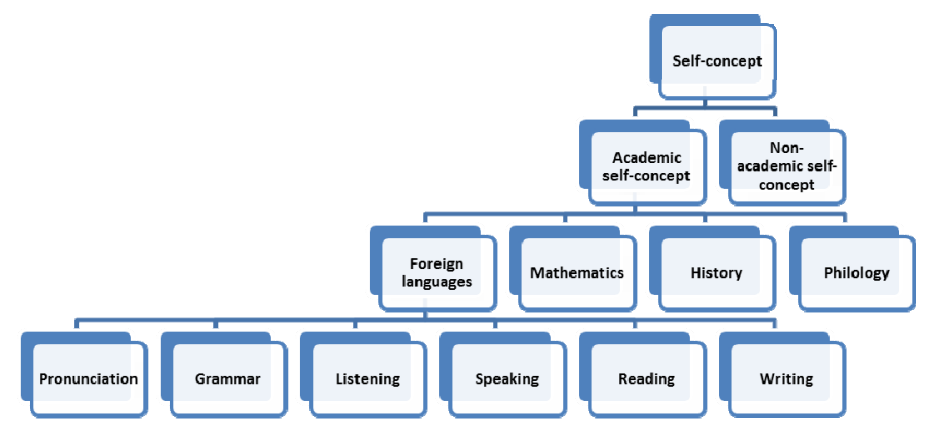

Figure 1 .

These self-concepts and global English self-concept interact and depend on each other; changes of any one of them cause the changes of others accordingly.

\subsection{The Impact of Pronunciation Self-Concept on English Learning}

Previous studies have reasoned the relationship between English pronunciation and English learning and drew the following conclusion: one who has bad pronunciation tends to fear the exposure of his flaw in front of peer students and teacher when practicing spoken English in class. Therefore, the psychological barrier is built and silence is employed to resist English learning. Most worst of all, some students stop English input. The psychological reaction to pronunciation may lead to the letdown of motivation and confidence of learning English. On the contrary, the ones who learn pronunciation successfully tend to obtain the admiration from classmates and praise from teachers (Horwitz, E. K., Horwitz, M. B. \& Cpe, J. A., 1985). The successful self-image can stimulate the motivation and confidence for the improvement of learning.

Theoretically, English pronunciation self-concept correlates to English performance, and it can help forecast English academic self-concept. Although pronunciation occupies portion of English learning, it has the most obvious impact on English academic self-concept compared with the skills and knowledge of listening, reading, writing, grammar and vocabulary, especially at the beginning of learning. Because at this time the English academic self-concept has not formed completely and it is easily influenced by pronunciation learning. Pronunciation learning involves not only the correct phonetic symbols and imitation of intonations, but also the learners' assessment to English learning, the confidence of learning and whether the learning can be sustained or not. Therefore, English pronunciation is supposed to be paid more attention at the very beginning of English learning to cultivate positive English pronunciation self-concept. It is essential to guide the students to clear the barrier of learning a new language and experience the sweetness of standard pronunciation (Byrne, B. M., 1996). In doing so, the correct English academic self-concept can be formed which lay a solid foundation for future learning.

\subsection{Literary Review}

The English educators have been concerned about the formation of English pronunciation self-concept for a long period. The study of Marsh, Graven and Melnerney (2003) showed that academic self-concept interacts with academic performance, that is, the self-concept of certain subject has impact on according academic performance and vice versa.

Chuming Wang reckoned that English pronunciation may facilitate or hinder English acquisition and put forward second language pronunciation learning hypothesis. Afterwards he conducted a series of experiments which revealed that English pronunciation self-concept correlates to English learning. Meanwhile, self-concept relates to English class anxiety (Shichang Xu \& Yanchun Cao, 2012). Xiuquan Zhu studied the relationship of English global self-concept, English pronunciation self-concept and English class anxiety. The results showed that English pronunciation self-concept forms in the process of English pronunciation learning; the proficiency of English pronunciation has impact on the self-assessment of students studying English. Furthermore, the English class anxiety and English learning is influenced to some degree (Xian Liang, Hai'an Pan \& Huizhen Fu., 2010). The objects of study above varied from middle school students to college students, the cognitive and psychological characteristics of college students may differ from middle school students. Does their English pronunciation self-concept correlate to English learning? Rare related studies have been made.

Recently, the second language acquisition gradually turns its step to the study of learners' psychology. Self-concept has been studied extensively in the field of psychology, but it is seldom studies in second language 
acquisition. English pronunciation self-concept is the variable which should not be neglected because the role it plays in the process of foreign language learning. To make a further study about the pronunciation self-concept has practical significance to the improvement of English education and the performance of students.

\subsection{Hypotheses and Research Design}

It was supposed that English pronunciation self-concept correlates to English learning and proved to some degree that English pronunciation can facilitate or hinder English learning among certain people (Shavelson, R. J., J. J. Hubner \& G. G. Stanton., 1976). Combining with the second language pronunciation learning hypothesis, this study intends to explore the relationship of English pronunciation self-concept, global English self-concept, English class anxiety and the actual performance of English of non-English major college students, aiming to stimulate English learning and facilitate English education.

\section{Methods and Procedures}

\subsection{Objectives}

This study aims to figure out the following: (1) the relationship of global English self-concept and each sub-dimension of it; (2) the relationship of English pronunciation self-concept and actual performance of English; (3) the relationship of global English self-concept and English pronunciation self-concept and (4) the relationship of English pronunciation self-concept and English classroom anxieties.

\subsection{Objects of Study}

More than three hundred non-English major college student volunteers are chosen at random in Beijing Institute of Petro-chemical Technology as the objects of study. All of them had learned English for more than six years. The volunteers ranged from freshmen to juniors, among whom 143 were male and 94 were female college students.

\subsection{Instruments}

The study instruments include questionnaire, tests, Excel and SPSS.

\subsubsection{Questionnaire}

The contents of questionnaire took the appendix of Chuming Wang's Chinese Students' Self-concept of English Learning (2008) and Xiuquan Zhu's questionnaire (2005) as reference to design. The questionnaire employed Likert's five-level scale to collect the marks.

\subsubsection{Tests}

The tests are composed of global tests and pronunciation tests. The global test is taken form College English Test band-4. The pronunciation test is divided into two steps: the volunteers were first asked to read ten sentences and a paragraph which are recorded by Cool Edit, and then the audio samples were evaluated by two teachers.

\subsubsection{SPSS}

The social scientific software SPSS (Statistical Package for the social sciences) was employed to analyze the data collected.

\subsection{Procedures}

\subsubsection{The Selection of Volunteers}

In the study, 237 non-English major college student volunteers were chosen, among whom 143 were male and 94 female students from Beijing Institute of Petro-chemical Technology. They were recruited from all over the college by posters and teachers in class. All of the volunteers had studied English for more than 6 years and they mostly came from Beijing, China. In order to keep the validity of the study, all the volunteers were not been recruited until they had passed a simple interview to make sure that they can follow through the steps needed.

\subsubsection{The Survey of Questionnaires}

In this part, the volunteers are required to answer a series of questions in the questionnaires. The questionnaire was composed of 50 questions which were supposed to be finished in less than 30 minutes. And the questions are classified into parts: the global English self-concept; the English pronunciation self-concept; the English classroom anxieties; the assessment by significant others and the motivation of English learning. Altogether 237 questionnaires were handed out and $100 \%$ was taken back while among which 13 were invalid because of nonstandard filling. 


\subsubsection{The Tests of Pronunciation and Global English Performance}

The pronunciation tests were completed orally. The pronunciation tests were divided into two steps: the volunteers were first asked to read ten sentences and then a short paragraph which were recorded by Cool Edit, and then the audio samples were evaluated by two teachers. The scores given by the two teachers then were averaged. And the volunteers were required to choose the best choices given in each question taken from College English band-4 within 90 minutes. In order to make the tests valid, the subjective questions were all deleted.

\subsubsection{Data Collection and Analysis}

The above data were firstly input into Excel for preparatory process and then were delivered to SPSS for analysis.

\section{Conclusions}

\subsection{The Relationship of Each Dimension of Global English Self-Concept}

The related statistics show that reading, listening, grammar and so on correlate to global English self-concept.

Table 1. The correlation of global English self-concept and its dimensions

\begin{tabular}{|c|c|c|c|c|c|}
\hline & $\begin{array}{l}\text { Global } \\
\text { self-concept }\end{array}$ & $\begin{array}{l}\text { Pronunciation } \\
\text { self-concept }\end{array}$ & $\begin{array}{l}\text { Grammar } \\
\text { self-concept }\end{array}$ & $\begin{array}{l}\text { Listening } \\
\text { self-concept }\end{array}$ & $\begin{array}{l}\text { Reading } \\
\text { self-concept }\end{array}$ \\
\hline $\begin{array}{l}\text { Global } \\
\text { self-concept }\end{array}$ & 1.00 & .642 & .608 & .594 & .629 \\
\hline $\begin{array}{l}\text { Pronunciation } \\
\text { self-concept }\end{array}$ & & 1.00 & .408 & .649 & .418 \\
\hline $\begin{array}{l}\text { Grammar } \\
\text { self-concept }\end{array}$ & & & 1.00 & .336 & .572 \\
\hline $\begin{array}{l}\text { Listening } \\
\text { self-concept }\end{array}$ & & & & 1.00 & .512 \\
\hline $\begin{array}{l}\text { Reading } \\
\text { self-concept }\end{array}$ & & & & & 1.00 \\
\hline
\end{tabular}

Description: as shown in Table 1, all the dimensions concerned correlated to global English self-concept. Among which pronunciation self-concept and reading self-concept ranked one and two. The pronunciation plays a significant role in global English self-concept; the change of pronunciation self-concept is likely to change the learner's global self-concept.

\subsection{The Relationship of English Pronunciation Self-Concept and Actual Performance of English}

It was once supposed that the English pronunciation self-concept significantly correlated too the actual performance of English. Yet in this study, the statistic indicted that college students' pronunciation self-concept was not so correlated to their global English performance as middle school students whose self-concept was not as multidimensional and structural as the college ones. Another reason is that under the present study and test patterns, the students paid more attention to written performance but not to oral performance. They just think that the nonstandard influence the oral presentation and discussion in class but not the global English performance.

Table 2. The correlation of English pronunciation self-concept and the actual performance of English

\begin{tabular}{llllll}
\hline & $\begin{array}{l}\text { Maximum } \\
\text { value }\end{array}$ & $\begin{array}{l}\text { Minimum } \\
\text { value }\end{array}$ & Average value & $\begin{array}{l}\text { Standard } \\
\text { deviation }\end{array}$ & Correlation \\
\hline $\begin{array}{l}\text { English } \\
\text { performance }\end{array}$ & 89 & 47 & 70.5 & 11.81 & 0.325 \\
\hline $\begin{array}{l}\text { Pronunciation } \\
\text { self-concept }\end{array}$ & 59 & 18 & 39.4 & 1.410 & 1 \\
\hline
\end{tabular}

Description: as shown in Table 2, the correlation of English pronunciation self-concept to the actual performance of English is 0.325 . 


\subsection{The Relationship of Global English Self-Concept and English Pronunciation Self-Concept}

One of the most important relationships which are supposed to be studied is whether the English pronunciation self-concept and the global English self-concept correlated or not.

Table 3. The correlation of English pronunciation self-concept and the global English self-concept

\begin{tabular}{llll}
\hline & $\begin{array}{l}\text { The English } \\
\text { self-concept }\end{array}$ & pronunciation & The global English self-concept \\
\hline $\begin{array}{l}\text { English } \\
\text { self-concept }\end{array}$ & pronunciation & .462 \\
\hline
\end{tabular}

Description: as shown in Table 3, the English pronunciation self-concept and the global English self-concept is significantly correlated. When the English pronunciation self-concept is high, the global English self-concept is high accordingly.

\subsection{The Relationship of English Pronunciation Self-Concept and English Class Anxieties}

Table 4. The correlation of English pronunciation self-concept and English classroom anxieties

\begin{tabular}{llllll}
\hline & $\begin{array}{l}\text { The performance } \\
\text { English pronunciation }\end{array}$ & of & $\begin{array}{l}\text { The performance } \\
\text { English }\end{array}$ & $\begin{array}{l}\text { The English classroom } \\
\text { anxieties }\end{array}$ & \\
\hline $\begin{array}{l}\text { English } \\
\text { pronunciation } \\
\text { self-concept }\end{array}$ & .168 & .179 & -.307 & \\
\hline
\end{tabular}

Description: the English pronunciation self-concept to the performance of English pronunciation and the actual performance of English is not so correlated, but the English pronunciation self-concept and the English classroom anxieties is negative correlated. That is, the higher the English pronunciation self-concept is, the lower the English classroom anxieties.

\section{Discussion}

The English pronunciation self-concept has not earned enough attention either from teachers or students, and it is taken into consideration at the beginning of English learning. No relevant tests are made and there are no restrict requirements. Some students feel the pressure form the lack of pronunciation practice. They take it for granted that their pronunciation is not standard which prevents them from speaking in English in class. Although the performance is not so bad, he students still lack of confidence and passion which are indispensible to the improvement of English. Some teachers of English hold that the teaching of pronunciation belongs to the beginning of English learning, the opportunities of practicing pronunciation is reduced. The mistaken understanding of paying more attention to vocabulary but to pronunciation is universal. Thus, it is important to remind and guide students to practice pronunciation in English learning for teachers of English. That is, whether the teachers can help students form positive pronunciation self-concept or not play a critical role to English education (Marsh, H. M. \& R. O’Neil, 1984).

Up to now, the studies revolving around the second language pronunciation learning hypothesis has only been conducted in certain cities, the universality of it still needs to be further demonstrated; it mostly concerned about the English learning in elementary stage, the issues in college has been rarely studied. The mechanism and the formation of the relationship between academic records and self-concept have not been covered. Just as Karsh has pointed out that there may be variable and direct connection between how to learn and self-concept, even though the connection between academic records and self-concept is not so direct (Wenchun Li., 2010). More future studies can direct into whether the language learners' pronunciation self-concept correlate to their motivation and strategies, the relationship between pronunciation self-concept and individuals, how to help learners build positive pronunciation self-concept. The answers of these questions may play an instructive role in the future English education. 


\section{Acknowledgements}

I wish to thank Jiaolan Yan for her valuable suggestions on earlier versions of this article. Thanks also to Weiran Zhang for her constructive criticism. My thanks also go to Shengqi Zhang for his assistance in data collection. I especially thank my family and friends for their support.

\section{References}

Arnold, J. (1999). Affect in language learning. Cambridge: Cambridge University Press.

Byrne, B. M. (1996). Measuring self-concept across the life span: Issues and instrumentation. Washington: American Psychological association. http://dx.doi.org/10.1037/10197-000

Chuming Wang. (2004). Self-concept, English pronunciation and EFL learning. Foreign Language Teaching and Research, 1, 56-64. http://dx.doi.org/10.3969/j.issn.1000-0429.2004.01.009

Chuming Wang. (2004). English pronunciation self-concept and actual pronunciation performance. Foreign Language World, 5, 62-67.

Gass, S., \& L. Selinker. (2001). Second language acquisition: An introductory course (2nd ed.). New Jersey: Lawrence Erlbaum.

Gimson, A. C. (1980). An introduction to the pronunciation of English (3th ed.). London: Edward Arnold, Ltd.

Guay, F., H. M. Marsh, \& M. Boivin. (2003). Academic self-concept and academic achievement: Development perspectives on their casual ordering. Journal of Educational Psychology, 98, 124-136.

Hattie, J. (1986). Self-concept. New Jersey: Erlbaum.

Horwitz, E. K., Horwitz, M. B., \& Cpe, J. A. (1985). Foreign language classroom anxiety. Modern Language Journal, 2, 125-132. http://dx.doi.org/10.2307/327317

Marsh, H. W., \& R. J. Shavelson. (1985). Self-concept: Its multifaceted, hierarchical structure. Educational Psychologist, 20, 107-125.

Marsh. H. W., Graven, R. G., \& Melnerney, D. M. (2003). International advances in self-research. Charlotte: Information Age Publishing.

Marsh, H. M., \& R. O’Neil. (1984). Self-description questionnaire III: The construct validity of multi-dimensional self-concept ratings by late-adolescence. Journal of Educational Measurement, 21.

Marsh, H. W., \& A. S. Yeung. (1993). Casual effects of academic self-concept on academic achievement structural equation models of longitudinal data. Journal of International Psychology, 89, 41-54.

Shavelson, R. J., J. J. Hubner, \& G. G. Stanton. (1976). Validation of construct interpretation. Review of Educational Research, 3, 407-441. http://dx.doi.org/10.2307/1170010

Shichang $\mathrm{Xu}$, \& Yanchun Cao. (2012). Research in relevance between the phonetic self-concept and English learning. Journal of Xinjiang Normal University (Social Sciences), 2, 98-101.

Wenchun Li. (2010). The relationship between the self-concept of the pronunciation and oral level of English majors. Journal of Zhangzhou Institute of Technology, 4, 59-62. http://dx.doi.org/10.3969/j.issn.1673-1417.2010.04.014

Xian Liang, Hai'an Pan, \& Huizhen Fu. (2010). Analysis on the relation between pronunciation ability and English proficiency from the perspective of student's English self-concept. Journal of Xihua University (Philosophy \& Social Sciences), 6, 102-107. http://dx.doi.org/10.3969/j.issn.1672-8505.2010.06.021

Xiuquan Zhu. (2005). The relationship of global English self-concept, English pronunciation self-concept and the English classroom anxieties. Journal of international affairs, 4, 61-65. 